\title{
PENGARUH TERAPI CONTRAST BATH (RENDAM AIR HANGAT DAN AIR DINGIN) TERHADAP OEDEMA KAKI PADA PASIEN CONGESTIVE HEART FAILURE
}

\author{
Silvia Nora Anggreini ${ }^{1 *}$, Rizki Amelia ${ }^{2}$ \\ ${ }^{1,2}$ STIKes Pekanbaru Medical Center, Jl. Lembaga Pemasyarakatan No. 25 Gobah \\ Email : vissdeus@gmail.com
}

Diterima : November 2021, Diterbitkan: Desember 2021

\begin{abstract}
ABSTRAK
Congestive Heart Failure (CHF) adalah ketidakmampuan otot jantung memompakan sejumlah darah untuk memenuhi kebutuhan metabolic tubuh. Dibeberapa pasien penderita CHF secara umum mengalami oedema pada ekstremitas bawah. Oedema menyebabkan penurunan fungsi kesehatan dan kualitas hidup, ketidaknyamanan, dan perubahan postur tubuh. Salah satu bentuk manejemen hypervolemia adalah terapi Contrast Bath yang merupakan perawatan dengan rendam kaki sebatas betis secara bergantian dengan menggunakan air hangat dan dilanjutkan dengan air dingin. Tujuan dari penelitian ini adalah Untuk Mengetahui apakah ada Pengaruh Terapi Contrast Bath (Rendam Air Hangat Dan Air Dingin) Terhadap Oedema Kaki Pada Pasien Congestive Heart Failure. Jumlah responden 16 orang. Jenis penelitian ini adalah penelitian kuantitatif dengan desain pre eksperimental dan menggunakan rancangan one group pre-post test desaign. Berdasarkan analisa bivariat dapat dilihat hasil uji paired sample $T$ test dimana terdapat perbedaan pengaruh terapi Contrast Bath (rendam air hangat dan air dingin) terhadap perubahan ukuran oedema kaki pasien CHF, dengan ratarata (mean) 1,750 dan nilai $P$ Value 0,000 $(<0,05)$. Untuk penelitian selanjutnya penelitian ini dapat dilanjutkan tentang pengaruh dukungan keluarga terhadap psikologis pasien penderita CHF rawat jalan.
\end{abstract}

Kata Kunci $\quad$ : Contrast Bath, Congestive Heart Failure, Oedema

\begin{abstract}
Congestive Heart Failure (CHF) is the inability of the heart muscle to pump blood to meet the body's metabolic needs. Some patients with CHF generally experience edema of the lower extremities. Edema causes decreased health function and quality of life, discomfort, and changes in posture. One form of hypervolemia management is the Contrast Bath therapy, which is a treatment by alternating calf-length soaking of the feet using warm water followed by cold water. The purpose of this study was to determine whether there is an effect of Contrast Bath Therapy (Warm and Cold Water Soaking) on Foot Edema in Congestive Heart Failure Patients. The number of respondents was 16 people. This type of research is a quantitative study with a pre-experimental design and uses a one group pre-post test design in a desaign. Based on the bivariate analysis, the results of the paired sample T test can be seen where there is a difference in the effect of Contrast Bath therapy (soaking in warm and cold water) on changes in the size of the edema of the feet of CHF patients, with an average (mean) of 1.750 and a $P$ value of $0.000(<0,05)$. For further research, this study can be continued on the effect of family support on the psychological outpatients with CHF.
\end{abstract}

Keywords: Contrast Bath, Congestive Heart Failure, Oedema 


\section{PENDAHULUAN}

Congestive Heart Failure (CHF) adalah ketidakmampuan otot jantung memompakan sejumlah darah untuk memenuhi kebutuhan metabolik tubuh. CHF adalah sebuah kondisi dari kardiovaskuler dimana jantung tidak bisa memompa darah secara adekuat untuk memenuhi kebutuhan metabolisme dari jaringan tubuh (Desai dkk, 2012). Gagal jantung kongestif merupakan satu - satunya penyakit kardiovaskuler yang terus meningkat insiden dan prevalensinya. Setengah dari pasien yang terdiagnosa gagal jantung masih mempunyai harapan untuk hidup selama 5 tahun (Pangastuti, 2009).

Gejala penyakit $\mathrm{CHF}$ yang biasa muncul adalah extertional dyspnoea, orthopnoea, paroxysmal nocturnal dyspnoea, batuk kering, kelelahan dan kelemahan, pusing atau palpitasi. Gejala penyakit $\mathrm{CHF}$ yang berkaitan dengan retensi cairan adalah nyeri epigastrik, distensi abdomen, ascites, oedema sakral dan oedema peripheral (Panel, 2011). Persentase gejala pada CHF adalah dispnoea (52\%), orthopnoea (80\%), paroxysmal nocturnal dyspnoea (76\%), oedema (81\%) (Remme, 2011).

Berdasarkan data risiko kematian akibat gagal jantung berkisar antara 5-10\% pertahun pada gagal jantung ringan yang akan meningkat menjadi $30-40 \%$ pada gagal jantung berat (WHO, 2015). Congestive Heart Failure (CHF) merupakan penyebab kematian nomor satu di dunia (Pusdatin, 2013). Jumlah gagal jantung di Amerika Serikat kira-kira 5,7 juta orang dewasa dan 550.000 kasus baru di diagnosis setiap tahunnya diagnosis (Mozaffarian, 2016). Gagal jantung berkontribusi terhadap 287.000 kematian per tahun. Sekitar setengah dari orang yang mengalami gagal jantung meninggal dalam waktu lima tahun setelah di diagnosis (Emory Health Care, 2018). Negara Indonesia menduduki peringkat keempat penderita gagal jantung kongestif terbanyak di Asia Tenggara setelah negara Filipina, Myanmar dan Laos (Lam, 2015). Prevalensi penyakit gagal jantung di Indonesia tahun 2013 sebesar 229.696 orang, sedangkan berdasarkan gejala yang di diagnosis oleh dokter yaitu sebesar 530.068 orang. Provinsi Jawa Tengah merupakan provinsi dengan jumlah terbanyak nomor 3 yaitu sebanyak 43.361 orang, setelah Jawa Timur dengan jumlah 54.826 orang dan Jawa Barat dengan jumlah 45.027 orang dari 33 provinsi yang ada di Indonesia (Pusdatin, 2013).

Laporan hasil data dari Dinas Kesehatan Kota Pekanbaru tahun 2019 terdapat \pm 124 orang penderita Congestive Heart Failure. Data Puskesmas Harapan Raya Pekanbaru pada tahun 2019 diperoleh bahwa penderita Congestive Heart Failure berjumlah 90 orang, dan rata rata berada pada golongan usia 45-65 tahun (Dinkes Kota Pekanbaru, 2019). Hasil survey pendahuluan yang dilakukan pada hari jumat tanggal 17 Juli 2020 di Puskesmas Harapan Raya Pekanbaru diperoleh data sebanyak 35 pasien yang menderita Congestive Heart Failure pada 06 bulan terakhir dari bulan Januari 2020 sampai dengan bulan Juni 2020.

Berdasarkan hasil wawancara dan observasi yang dilakukan pada tanggal 17 Juli 2020 dibeberapa pasien yang menderita chf diperoleh hasil bahwa masalah umum yang dialami penderita adalah oedema pada bagian ekstremitas bawah. Hal ini terjadi akibat dari kondisi vena yang terbendung (congesti), terjadi peningkatan tekanan hidrostatik intravaskuler (tekanan yang mendorong darah mengalir di dalam vaskuler oleh kerja pompa jantung) menimbulkan perembesan cairan plasma ke dalam ruang interstitium. Cairan plasma ini akan mengisi pada sela-sela jaringan ikat longgar dan rongga badan maka terjadi edema(Grossman, 2009). Oedema kaki akan menyebabkan penurunan fungsi kesehatan dan kualitas hidup (HR-QOL), ketidaknyamanan, perubahan postur tubuh, menurunkan mobilitas dan meningkatkan resiko jatuh, gangguan sensasi di kaki dan menyebabkan perlukaan di kulit (Rahnavard, 2014). Dapat disimpulkan bahwa oedema pada pasien CHF merupakan masalah keperawatan kelebihan volume cairan.

Prinsip penatalaksanaan gagal jantung kongestif dilakukan dengan 2 cara sebagai berikut. terapi farmakologis dan non farmakologis. Upaya yang telah dilakukan pemerintah dalam 
melakukan penekanan faktor resiko yaitu dengan menggunakan terapi farmakologis (Kemenkes, RI, 2018), namun terapi tersebut belum optimal (Flora, 2012). Jenis terapi farmakoogis yang dapat diberikan pada pasien dengan gagal jantung kongestif yaitu golongan obat diuretic Furosemide (Lasix), Asam etakrinat (Edecrin), Klorotiazid (Diuril) Inhibitor Angiotensin Converting Enzyme (ACE) Penyekat Beta Angiotensin II (ARB) (Muttaqin, 2014)

Efek samping dari terapi Farmakologis pada pasien CHF yang mengkonsumsi bloker reseptor adrenergic dapat menyebabkan gagal jantung dan meningkatkan resistensi jalan napas yang dapat meningkatkan serangan asma pada pasien dengan riwayat asma. Bloker juga dapat menyebabkan ekstremitas menjadi dingin. Dapat menimbulkan rasa lelah, gangguan tidur dan depresi.

Upaya untuk meminimalkan efek samping farmakologis, maka perlu pendekatan nonfarmakologis. Pendekatan non farmakologis yang bisa dilakukan antara lain pembatasan natrium, alkohol, kontrol rutin, olahraga, perubahan gaya hidup, dan terapi contrast bath.

Salah satu bentuk manejemen hypervolemia adalah terapi contrast bath yang merupakan perawatan dengan rendam kaki sebatas betis secara bergantian dengan menggunakan air hangat dan dilanjutkan dengan air dingin, dimana suhu dari air hangat antara $36,6-43,3^{\circ} \mathrm{C}$ dan suhu air dingin antara $10-20{ }^{\circ} \mathrm{C}$ (Sabelman, 2004 dalam Purwadi, 2015). Dengan merendam kaki yang edema dengan terapi ini akan mengurangi tekanan hidrostatik intra vena yang menimbulkan pembesaran cairan plasma ke dalam ruang interstisium dan cairan yang bererada di intertisium akan kembali ke vena sehingga edema dapat berkurang (Mcneilus, 2004 dalam Purwadi, 2015).

Hal ini sejalan dengan penelitian Purwadi (2015), dengan judul penelitian Pengaruh Terapi Contrast Bath (Rendam Air Hangat Dan Air Dingin) Terhadap Edema Kaki Pada Pasien Penyakit Gagal Jantung Kongestif yaitu dengan hasil menunjukkan bahwa adanya pengaruh terapi contrast bath terhadap edema kaki pada pasien penderita penyakit gagal jantung kongestif dengan hasil edama kaki pada pasien pretest dan postest pada kelompok perlakuan yaitu 6,11 dan 3,44 sedangkan pada kelompok kontrol yaitu 5,78 dan 5,00, ada perbedaan edema kaki pretest dan postest kelompok perlakuan ( $p$-value 0,000), ada perbedaan edema kaki pretest dan postest kelompok kontrol ( $p$-value 0,001$)$ serta $p$-value $(0,034)<\alpha(0,05)$.

Berdasarkan masalah diatas, peneliti tertarik untuk melakukan penelitian tentang pengaruh terapi contrast bath terhadap oedema kaki pada pasien penderita penyakit gagal jantung kongestif di Puskesmas Harapan Raya.

\section{METODOLOGI}

Jenis penelitian ini adalah penelitian kuantitatif dengan desain pre eksperimental. Rancangan yang digunakan pada penelitian ini yaitu menggunakan one group pre-post test desaign. Rancangan ini melibatkan satu kelompok dengan terapi contrast bath (rendam air hangat dan air dingin). Hasil data yang diperoleh dari puskesmas harapan raya 3 bulan terakhir didapatkan 90 pasien yang mengalami CHF. Pada penelitian ini yang menjadi populasi dan subjek penelitian adalah seluruh pasien CHF yang mengalami oedema ektremitas bagian bawah sebanyak 35 orang. Pada penelitian ini yang menjadi sampel adalah semua pasien CHF yang mengalami oedema ektremitas bagian bawah yaitu berjumlah 34 responden di Wilayah Kerja Puskesmas Harapan Raya Pekanbaru. Adapun cara pengambilan sampel adalah 34 responden dibagi dua kelompok, 17 kelompok intervensi responden dan 17 kelompok kontrol responden

\section{HASIL DAN PEMBAHASAN}

Pada bab ini disajikan hasil penelitian yang telah dilakukan pada bulan Juli 2020 dengan memberikan 16 responden terapi contrast bath (rendam air hangat dan air dingin) terhadap perubahan ukuran oedema kaki pada pasien chf diwilayah kerja Puskesmas Harapan Raya Kecamatan Bukit Raya. Dan distribusi rata rata responden. adalah sebagai berikut: 
Tabel 1. Distribusi Frekuensi Responden Berdasarkan Karakteristik Jenis Kelamin

\begin{tabular}{ccc}
\hline $\begin{array}{c}\text { Jenis } \\
\text { Kelamin }\end{array}$ & Frequency & $\begin{array}{c}\text { Percentase } \\
(\mathbf{\%})\end{array}$ \\
\hline Laki-laki & 10 & 62,5 \\
\hline Perempuan & 6 & 37,5 \\
\hline Total & $\mathbf{1 6}$ & $\mathbf{1 0 0 . 0}$ \\
\hline
\end{tabular}

Berdasarkan table 4.1 didapatkan bahwa responden penelitian ini yang mayoritas adalah responden laki-laki yaitu sebanyak 10 orang responden $(62,5)$. Dengan total responden 16 orang responden.

Tabel 2. Distribusi Frekuensi Responden Berdasarkan Karakteristik Usia

\begin{tabular}{ccc}
\hline Usia & Frekuensi & $\begin{array}{c}\text { Presentase } \\
(\boldsymbol{\%})\end{array}$ \\
\hline $\begin{array}{c}\text { Middle } \\
\text { age }\end{array}$ & 3 & 18,8 \\
\hline Elderly & 5 & 31,3 \\
\hline Old & 8 & 50,0 \\
\hline Total & $\mathbf{1 6}$ & $\mathbf{1 0 0 . 0}$ \\
\hline
\end{tabular}

Berdasarkan table 4.2 didapatkan bahwa responden penelitian yang mayoritas adalah old yaitu sebanyak 8 orang responden $(50,0)$. Dengan total 16 orang responden.

Tabel 3. Distribusi Frekuensi Pre Test Dan Post Test Terapi Contrast Bath (Rendam Air Hangat dan Air Dingin) Terhadap Perubahan Ukuran Oedema Kaki Pada Pasien CHF

\begin{tabular}{lcc}
\hline & Frekuensi & Mean \\
\hline Pre Test Oedema & 16 & 7.38 \\
\hline Post Test Oedema & 16 & 5.63 \\
\hline Perbedaan & & $\mathbf{1 , 7 5 0}$ \\
\hline
\end{tabular}

Berdasarkan table 4.3 didapatkan bahwa nilai rata-rata hasil pengukuran oedema saat pre test adalah 7.38 . Dan nilai rata-rata hasil pengukuran oedema saat post test adalah 5.63. Rata-rata perbedaan sebelum dan sesudah dilakukan terapi contrast bath (rendam air hangat dan air dingin) adalah sebesar 1,750.
Analisa bivariate digunakan untuk melihat pengaruh pre dan post terapi contrast bath (rendam air hangat dan air dingin) terhadap perubahan ukuran oedema kaki pada pasien CHF Hasil penelitian ini dikatakan efektif apabila $\mathrm{p}$ value $<0.05$. Penelitian ini menggunakan dependent $T$ test. Berdasarkan hasil pengolahan data dengan menggunakan program SPSS (statistical program for social science) diperoleh hasil sebagai berikut:

Berdasarkan hasil uji normalitas pada table didapatkan bahwa distribusi data sebelum intervensi pada penelitian ini adalah normal yaitu nilai sig. 0,984 dan data sesudah intervensi pada penelitian ini adalah normal yaitu nilai sig. 0,683 , jika nilai sig. $<0.05$ maka distribusi data tersebut tidak normal. Jika nilai sig. > 0.05 maka data tersebut terdistribusi dengan normal.

Tabel 4. Table Hasil Uji Paired Sampel T Test Perubahan Ukuran Oedema

\begin{tabular}{ccccc}
\hline & N & Mean & $\begin{array}{c}\text { Std. } \\
\text { devisiasi }\end{array}$ & P Value \\
\hline Pre & 16 & 7.38 & 1.310 & 0.000 \\
post & 16 & 5.63 & 1.258 & \\
\hline
\end{tabular}

Berdasarkan table 4 diatas dapat dilihat hasil uji Paired sampel $\mathrm{T}$ Test didapatkan bahwa efektifitas dari terapi Contrast Bath (rendam air hangat dan air dingin) memiliki signifikansi 0.000 yang artinya terdapat perbedaan yang signifikan sebelum dengan sesudah dilakukan terapi Contrast Bath (rendam air hangat dan air dingin) terhadap perubahan ukuran oedema kaki pada pasien $\mathrm{CHF}$ diwilayah kerja puskesmas harapan raya. Dapat disimpulkan bahwa terapi Contrast Bath (rendam air hangat dan air dingin) mempengaruhi perubahan ukuran oedema kaki pada pasien congestive heart failure (CHF).

Berdasarkan hasil penelitian yang telah dilakukan pada 16 responden, maka pada bab ini akan dibahas secara sistematis dari hasil analisis uji statistic tentang pengaruh terapi contrast bath (rendam air hangat dan air dingin) terhadap oedema kaki pada pasien CHF diwilayah kerja puskesmas harapan raya. Pembahasan dalam 
penelitian ini adalah dengan melihat teori dan penelitian terkait dilakukan oleh peneliti yang lain relevan dengan penelitian saat ini.

Diketahui bahwa jumlah responden seluruhnya sebanyak 16 orang responden. Responden perempuan sebanyak 6 orang $(37,5)$ dan responden laki laki sebanyak 10 orang $(62,5)$. Persentase kejadian yang didiagnosa gagal jantung lebih sedikit terjadi pada wanita disebabkan perempuan sebelum menopause memiliki hormon estrogen yang berperan memproteksi perempuan dari berbagai penyakit kardiovaskuler. Hal ini mengakibatkan peluang perempuan terkena gagal jantung lebih rendah daripada laki-laki. Hormon estrogen dapat meningkatkan rasio HDL (High Density Lipoprotein) sebagai faktor pelindung dalam mencegah proses atherosclerosis (Hamzah, 2016). Namun demikian, hormon estrogen pada wanita menopause akan menurun sehingga sifat proteksi wanita terhadap resiko terkena penyakit jantung juga akan menurun. Hal ini mengakibatkan wanita akan berisiko terkena penyakit jantung yang sama dengan pria (Sulistiyowatiningsih et al., 2016).

Karakteristik subjek penelitian dikelompokkan berdasarkan jenis kelamin, usia, total lama rawat inap dan penyakit penyerta. Total dari 106 subjek penelitian yang sesuai dengan kriteria inklusi, terdapat 53 kasus (50\%) pasien berjenis kelamin pria dan terdapat 53 kasus $(50 \%)$ pasien berjenis kelamin perempuan. Hasil penelitian ini menunjukkan bahwa perbandingan antara kasus pasien laki-laki dan kasus pasien perempuan yang didiagnosis gagal jantung adalah sama. Hasil penelitian ini sesuai dengan penelitian Apselima (2016) yang melaporkan dari total 16 subjek diketahui pasien yang diagnosis gagal jantung berjenis kelamin lakilaki sebanyak 8 orang (50\%) sedangkan pasien berjenis kelamin perempuan sebanyak 8 orang $(50 \%)$.

Kemampuan jantung untuk memompa darah ke seluruh tubuh dipengaruhi oleh beberapa faktor salah satunya adalah usia responden, Seiring dengan perkembangan usia semakin banyak permasalahan dan tingkat stressor yang di hadapi dapat mempengaruhi kualitas hidup seseorang, individu yang telah memasuki usia dewasa atau lanjut usia sering di hadapkan dengan kondisi seperti perubahan fisik yang semakin lemah sehingga berdampak pada kemampuan jantung untuk melakukan tugasnya (Bowman dkk, 2006 dalam Budiono, 2019). Dilihat dari hasil karakteristik responden berdasarkan usia responden didapatkan bahwa rata-rata usia responden adalah 48,44 dan umur minimum adalah 33 tahun sedangkan umur maximum adalah 75 tahun.

Beberapa peneliti juga membuktikan bahwa umur seseorang sangat berpengaruh terhadap kualitas fungsi jantung seperti penelitian yang dilakukan oleh (Rori Hamzah, 2016 dalam Budiono, 2019) di Rs PKU Muhammadiyah Yogyakarta tentang hubungan usia dan jenis kelamin dengan kualitas hidup penderita gagal jantung, bahwa seluruh responden yang berusia $>65$ tahun memiliki kualitas hidup yang kurang dari (100\%) didapatkan hasil uji kendall tau menunjukkan $\mathrm{P}$ value $0,001<\alpha 0,05$.

Pada usia 45-54 tahun, jumlah pasien yang mengalami gagal jantung $4 \mathrm{x}$ lipat dibanding usia 35-44 tahun, usia 55-64 tahun sebesar 1x lipat dibanding usia 45-55 tahun, usia 65-74 tahuan sebesar 1,5x lipat dibanding usia 55-64 tahun dan pada usia $\geq 75$ tahun mengalami penurunan 1,5x lipat daripada usia 65-74 tahun yang mengalami gagal jantung. Hal ini menunjukkan bahwa semakin bertambahnya usia semakin meningkat angka insidensi kejadian terkena gagal jantung.

Asumsi peneliti, karakteristik responden Seiring dengan perkembangan usia semakin banyak permasalahan dan tingkat stressor yang di hadapi dapat mempengaruhi kualitas hidup seseorang, individu yang telah memasuki usia dewasa atau lanjut usia sering di hadapkan dengan kondisi seperti perubahan fisik yang semakin lemah sehingga berdampak padakemampuan jantung untuk melakukan tugasnya.

Penelitian ini sesuai dengan penelitian Yulianti (2016) yang menunjukkan bahwa pasien yang 
menderita gagal jantung banyak ditemukan pada usia 45-54 tahun, usia 55-64 tahun, dan usia 6574 tahun, sedangkan pada usia $\geq 75$ tahun mengalami penurunan. Hal ini juga diperkuat dengan hasil Riset Kesehatan Dasar tahun 2013 yang menunjukkan angka kejadian gagal jantung tertinggi pada usia 45-54 tahun, 55-64 tahun dan 65-74 tahun serta menurun sedikit pada usia $\geq 75$ tahun (Kemenkes RI, 2018).

Asumsi peneliti, Persentase kejadian yang didiagnosa gagal jantung lebih sedikit terjadi pada wanita disebabkan perempuan sebelum menopause memiliki hormon estrogen yang berperan memproteksi perempuan dari berbagai penyakit kardiovaskuler. Hal ini mengakibatkan peluang perempuan terkena gagal jantung lebih rendah daripada laki-laki. Hormon estrogen dapat meningkatkan rasio HDL (High Density Lipoprotein) sebagai faktor pelindung dalam mencegah proses atherosclerosis.

\section{Pre Post Terapi Contrast Bath (Rendam Air Hangat Dan Air Dingin) Terhadap Oedema Kaki Pada Pasien CHF}

Berdasarkan table 3 diatas didapatkan bahwa nilai rata-rata hasil pengukuran oedema saat pre test adalah 7.38. Dan nilai rata-rata hasil pengukuran oedema saat post test adalah 5.63. Rata-rata perbedaan sebelum dan sesudah dilakukan terapi contrast bath (rendam air hangat dan air dingin) adalah sebesar 1,750.

Berdasarkan penelitian yang dilakukan (Purwadi, 2015) menunjukkan bahwa nilai rata - rata edema kaki setelah dilakukan latihan terapi contrast bath pada kelompok perlakuan adalah 3,44 $\mathrm{mm}$ dan nilai rata-rata edema kaki setelah dilakukan latihanterapi pada kelompok kontrol adalah 5,00 mm. Hasil uji statistik dengan uji independent $t$ test didapatkan nilai $p$ 0,034 , berarti ada pengaruh yang signifikan terapi contrast bath terhadap edema kaki pada pasien penderita penyakit gagal jantung kongestif pada kelompok kontrol maupun kelompok perlakuan di RSUD Ungaran, RSUD Ambarawa, RSUD Kota Salatiga dan RSUD Tugurejo Provinsi Jawa Tengah.

Gagal jantung kongestif adalah ketidakmampuan jantung untuk memompakan darah yang adekuat untuk memenuhi kebutuhan jaringan akan oksigen dan nutrisi (Mubarak, 2008). Gagal jantung kiri : kongesti paru menonjol pada gagal ventrikel kiri, karena ventrikel kiri tidak mampu memompa darah yang datang dari paru. Gagal jantung kanan : bila ventrikel kanan gagal, yang menonjol adalah kongesti visera dan jaringan perifer (Smeltzer \& Bare, 2008).

Edema ektremitas bawah adalah salah satu manifestasi dari gagal jantung kanan. Pada kondisi vena yang terbendung (congesti), terjadi peningkatan tekanan hidrostatik intra vaskuler (tekanan yang mendorong darah mengalir di dalam vaskuler oleh kerja pompa jantung) menimbulkan perembesan cairan plasma ke dalam ruang interstitium. Cairan plasma ini akan mengisi pada sela-sela jaringan ikat longgar dan rongga badan maka terjadi edema(Grossman \& Brown, 2009).

Asumsi peneliti, pada penelitian pre terapi contrast bath (rendam air hangat dan air dingin) dengan responden yang mengalami oedema kaki Pada kondisi vena yang terbendung (congesti), terjadi peningkatan tekanan hidrostatik intra vaskuler (tekanan yang mendorong darah mengalir di dalam vaskuler oleh kerja pompa jantung) menimbulkan perembesan cairan plasma ke dalam ruang interstitium. Hal ini sebagian besar klien dapat menyebabkan oedema pada ektremitas bagia bawah.

Berdasarkan hasil penelitian yang telah dilakukan pada 16 responden.. Terapi ini dilakukan satu kali satu hari di pagi hari dengan durasi 15 menit terapi contrast bath. Penelitian dilakukan selama 14 hari dengan pasien yang berbeda. Peneliti mengambil data pre terlebih dahulu setelah itu dilakukan terapi pada responden dan setelah dilakukan terapi diperiksa lagi ukuran oedema pasien post terapi.

Terdapat pengaruh yang signifikan setelah dilakukan terapi contrast bath dapat disimpulkan terapi ini berpengaruh terhadap perubahan ukuran oedema kaki pada pasien 
CHF. Berdasarkan output statistics diketahui asymp.sig.(2-tailed) bernilai 0,000. karena nilai 0,000 lebih kecil dari <0.05, maka dapat disimpulkan bahwa hipotesa diterima. Artinya ada perbedaan antara hasil pengukuran perubahan oedema sebelum dan sesudah dilakukan terapi. Sehingga dapat disimpulkan bahwa ada pengaruh terapi contrast bath (rendam air hangat dan air dingin) terhadap oedema kaki pada pasien CHF, perubahan ukuran oedema pada pasien CHF diwilayah kerja puskesmas harapan raya.

Berdasarkan tabel diatas dapat dilihat hasil uji Paired sampel T Test didapatkan bahwa correlastion dari terapi Contrast Bath (rendam air hangat dan air dingin) memiliki signifikansi 0.000 yang artinya terdapat perbedaan yang signifikan sebelum dengan sesudah dilakukan terapi Contrast Bath (rendam air hangat dan air dingin) terhadap perubahan ukuran oedema kaki pada pasien CHF diwilayah kerja puskesmas harapan raya. Dapat disimpulkan bahwa terapi Contrast Bath (rendam air hangat dan air dingin) mempengaruhi perubahan ukuran oedema kaki pada pasien CHF (CHF).

Data analisa diatas menunjukkan ada pengaruh terapi contrast bath (rendam air hangat dan air dingin) terhadap oedema kaki pada pasien CHF hal ini sejalan dengan peneliti (Purwadi, 2015) yang berjudul pengaruh terapi contrast bath (rendam air hangat dan air dingin) terhadap oedema kaki pada pasien $C H F$. Dengan Sebuah pemahaman yang jelas tentang patofisiologi sangat penting untuk mengelola masalah secara efektif.

Menurut Stems (2013) dalam penelitian purwadi 2015, dua langkah utama terjadi pada pembentukan edema: Pergerakan cairan dari kompartemen vaskuler ke kompartemen interstitial sebagai akibat dari perubahan dinamika, Retensi natrium dan air oleh ginjal. Cairan keluar dari kompartemen vaskuler mengurangi volume sirkulasi efektif dan perfusi akhirnya ginjal.Penurunan perfusi ginjal mengaktifkan sistem renin-angiotensinaldosteron, sehingga air dan retensi natrium oleh ginjal dan kembali volume plasma menuju normal.Mekanisme kompensasi ini membantu untuk membangun kembali volume plasma di kompartemen intravaskular.

Terapi contrast bath adalah Perawatan dengan berendam kaki sebatas betis secara bergantian dengan menggunakan air hangat dan dilanjutkan dengan air dingin, dimana suhu dari air hangat antara $36,6-43,3^{\circ} \mathrm{C}$ dan suhu air dingin antara $10-20^{\circ} \mathrm{C}$ (Sabelman, 2004 dalam Purwadi 2015). Dangan selisih waktu 3 menit di dalam air hangat dan 1 menit di air dalam dingin. Dilakukan kompres dengan kain handuk untuk bagian-bagian tubuh yang tidak dapat direndam air dengan mudah, yang membuat pembuluh - pembuluh darah mengembang atau menyempit bersamaan dengan panas dan dingin yang meningkatkan sirkulasi darah ke bagian tubuh yang dirawat (Purwadi, 2015).

Keadaan ini sesuai pendapat dari (Martin, 2005 dalam Purwadi, 2015) bahwa merendam kaki yang edema dengan terapi ini akan mengurangi tekanan hidrostatik intra vena (tekanan yang mendorong darah mengalir di dalam vaskula oleh kerja pompa jantung) yang menimbulkan pembesaran cairan plasma ke dalam ruang interstisium dan cairan yang bererada di intertisium akan kembali ke vena sehingga edema dapat berkurang.

Sama dengan dugaan yang peneliti tetapkan, perendaman air panas lama dalam siklus kedua contrast bath bisa menciptakan fluktuasi yang cukup dalam kecepatan darah arteri. Hasil penelitian (Yu Shih, 2012) dalam purwadi 2015 merekomendasikan bahwa waktu perendaman dari ekstremitas dalam air panas harus ditingkatkan secara bertahap selama fase pengobatan selanjutnya, (Yu Shih, 2012) dalam purwadi 2015 meneliti efek dari contrast bath dengan rasio yang berbeda dari pemanasan ke waktu pendinginan pada kecepatan darah arteri brakialis pada pria dan wanita muda.

Dalam penelitian ini peneliti berasumsi dengan melakukan terapi contras bath dapat membantu responden untuk mengurangi ukuran udem. Terapi ini dapat dilakukan secara mandiri oleh responden karena dengan adanya tekanan hidrostatik intra vena yang muncul ketika 
dilakukan terapi contras bath membantu responden mengurangi ukuran udem yang terjadi pada responden. Sejalan dengan penelitian (Purwadi 2015) contras bath dilakukan untuk membuat pembuluh pembuluh darah mengembang atau menyempit bersamaan dengan panas dan dingin yang meningkatkan sirkulasi darah ke bagian tubuh yang dirawat.

\section{SIMPULAN}

Berdasarkan hasil penelitian dan pembahasan mengenai pengaruh terapi Contrast Bath (rendam air hangat dan air dingin) terhadap oedema kaki pada psien chf terhadap perubahan ukuran oedema kaki pasien CHF di wilayah kerja puskesmas harapan raya pekanbaru maka hasil dari penelitian mengenai pengaruh terapi contrast bath (rendam air hangat dan air dingin) terhadap perubahan oedema kaki pada pasien CHF di wilayah kerja Puskesmas Harapan Raya

\section{UCAPAN TERIMAKASIH}

Terimakasih kepada kepala Puskesmas Harapan Raya Pekanbaru dan semua responden yang telah membantu penelitian ini.

\section{DAFTAR PUSTAKA}

American Heart Association (AHA). 2016. Ejection Fraction Heart Failure Measurement.

http://www.heart.org/HEARTORG/Condit ions/HeartFailure/Symptom

sDiagnosisofHeartFailure/Ejekction

FractionHeartFailureMeasurementUCm

Agustina, A., Afiyanti, Y., \& Ilmi, B. 2017. Pengalaman Pasien Gagal Jantung Kongestif Dalam Melaksanakan Perawatan Mandiri. Healthy-Mu Journal, 1((1).

Apselima, D. 2016. Identifikasi Drug Related Problem (DRP) Pada Penatala Laksanaan Pasien Congestive Heart Failure (CHF) di Instalasi Rawat Inap RS PKU Muhammadiyah Gamping, Universitas Muhammadiyah Yogyakarta.

Budiono, dkk. 2019. Pengaruh Pemberian Contrast Bath Dengan Elevasi Kaki 30 Derajat Terhadap Penurunan Derajat
Edema Pada Pasien Gagal Jantung Kongestif . Jurnal Keperawatan, Poltekkes Kemenkes Malang, Indonesia.

Clinical Guedeline Centre, 2010. Comprehensiv Heart Failure Practice Guedeline: 16, e1194.

Dinas Kota Pekanbaru, 2019. Data Pasien Congestive Heart Failure. Di Puskesmas Harapan Raya.

Desai, dkk. 2019. Kelainan dan Penyakit Gagal Jantung. Yogyakarta : Nuha Medika.

Engkartini, Karson. 2019. Pijat Kaki Efektif Menurunkan Foot Oedema Pada Penderita Congestive Heart Failure (Chf). Jurnal Keperawatan Medikal Bedah. (1-54).

Emory Heart Care, 2018. National Heart Failure Audit. British Sciety For Heart Failure.

Flora, R., Purwanto, S., Program, D., Ilmu, S., Fakultas, K., \& Sriwijaya, U. (2012). PENATALAKSANAAN NON FARMAKOLOGIS TERAPI PADA PENDERITA HIPERTENSI PRIMER DI, 124-131.

Grossman, S dan Brown, D. 2009. Congestive Heart Failure and Pulmunary Edema. Http://emedicine.medscape.com.

Hamzah, R. 2016. Hubungan Usia dan Jenis Kelamin dengan Kulits Hidup Pada Penderita Gagal Jantung di RS PKU Muhammadiyah Yogyakarta. Universitas Aisyiyah Yogyakarta.

Hidayat, A. Aziz Alimul. 2017. Metodologi Penelitian Keperawatan dan Kesehatan, Jakarta : Salemba Medika

Hastono, Susanto Priyo. 2016. Analisa Data Pada Bidang Kesehatan, Jakarta : Rajawali Pers.

Kementrian Kesehatan Republik Indonesia. 2018. Hasil Utama RISKESDAS 2018. 
Jakarta: Kementrian Kesehatan Badan Penelitian dan Pengembangan Kesehatan

Kasron, dkk. 2019. Pengaruh Ventilatory Muscle Training (VMT) Terhadap Penurunan Dyspnea Pada Penderita Congestive Heart Failure. Jurnal Medika Usada STIKes Al-Irsyad Al-Islamiyyah Cilacap. Vol 2.

Lam, C. S. P. (2015). Heart failure in Southeast Asia: facts and numbers. ESC Heart Failure, 2(2), $46-49$.

LeMone, Priscilla, Karen M. Burke, \& Gerene Bauldoff. 2015. Keperawatan Medikal Bedah Gangguan Eliminasi dan Gangguan Kardiovaskular, Jakarta : EGC

Lolita, dkk. 2019. Evaluasi Kerasional Dan Kuantitas Penggunanaan Anti Hipertensi Pada Pasien Gagal Jantung Di Instalasi Rawat Inap Rumah Sakit PKU Muhammadiyah Gamping Yogyakarta. Jurnal Prodi Farmasi, Fakultas Farmasi, Universitas Ahmad Dahlan, Yogyakarta.

Mozaffarian, E. J. Benjamin and dkk, "Heart Disease and Stroke Statistics - 2016 Update," American Heart Association, 2016.

Muttaqin, Arif. 2014. Asuhan Keperawatan Klien dengan Gangguan Sistem Kardiovaskuler dan Hematologi, Jakarta : Salemba Medika.

Pangastuti, D. 2009. Asuhan Keperawatan dengan Gagal Jantung Kongestif di Rumah Sakit Roemani Semarang.Semarang: Universitas Muhammadiyah Semarang.

Panel, P., Robert, A., Moe, G. W., Co-chair, F., Cheung, A., Costigan, J., Leblanc, M. (2011).The 2011 Canadian Cardiovascular Society Heart Failure Management Guidelines Update :Focus on Sleep Apnea, Renal Dysfunction , Mechanical Circulatory Support, and Palliative Care. CJCA, 27(3), 319-338.

Purwadi, I Ketut Agus Hida, Gipta Galih W, \& Dewi Puspita. 2015. Pengaruh Terapi Contrast Bath (Rendam Air Hangat Dan
Air Dingin) Terhadap Oedema Kaki Pada Pasien Gagal Jantung Kongestif. Jurnal Program Studi Keperawatan STIKes Ngudi Waluyo, 7 (1-7).

Pusdatin Kementerian Kesehatan RI 2013, Data penyakit kardiovaskuler, (22 Juli 2019).

Rachma, Lailia Nur. 2014. Patomekanisme Penyakit Gagal Jantung Kongestif. Jurusan Biologi, Fakultas Sains dan Teknologi UIN Maliki Malang, 4 (1-10).

Remme, Bekelman, D.B., Havranek, E.P., Becker, D.M., Kutner, J.S., Peterson, P.N., Wittstein, I. (2011).Syptomps, depression, and quality of life in patients with heart failure. Journal of Cardiac Failure, 13, 6438.

Rahnavard, Z., Nodeh, Z. H., \& Hatamipour, K. (2014). Congestive heart failure: Predictors of health-related quality of life in Iranian women. Contemporary Nurse, 47(1-2), 159-167.

ResearchGate, 2010. Contrast Bath What Do We Know About Their Use. Jurnal Of Hand Therapy, 343346.

Rispawati, Baik Heni. 2019. Pengaruh Konseling Diet Jantung Terhadap Pengetahuan Diet Jantung Pasien Congestive Heart Failure (Chf. Jurnal Program Studi Pendidikan Ners STIKes Fort de Kock Bukittinggi, Indonesia.

Santoso, Dwi Agung, Ernawati, \& M. Ali Maulana. 2015. Pengaruh Terapi Rendam Kaki Air Hangat Terhadap Penurunan Tekanan Darah Pada Lansia Penderita Hipertensi Di Wilayah Kerja Upk Puskesmas Khatulistiwa Kota Pontianak. Program Studi Keperawatan Fakultas Kedokteran Universitas Tanjungpura Pontianak, (1-11).

Satria, Bagus Rian. 2018. Pengaruh Rendam Kaki Air Hangat Terhadap Penurunan Tekanan Darah Pada Lansia Di Desa Jati Blimbing Rt 03 Rw 01 Kecamatan Dander 
Kabupaten Bojonegor. S1 Keperawatan Sekolah Tinggi Ilmu Kesehatan Majapahit Mojokerto, (1-16).

Simon, E, B. 2014 Leg Edema Assessment and Management. Medsurg Nursing, 23 (1) 4453. Retrieved From http://search.proguest.com/docview/15061 50605? accountid=38628

Siregar, C.J.P., dan Wikarsa, S., 2010, Teknologi Farmasi Sediaan Tablet DasarDasar Praktis, Penerbit Buku Kedokteran EGC, Jakarta. 54 - 55, 98 115 .

Sujarweni, V. Wiratna. 2014. Metodologi Penelitian Keperawatan, Yogyakarta : Gava Media.

Sulistiyowatiningsih, ending, dkk. 2016. Kajian Potensi Interaksi Obat Pada Pasien Gagal Jantung Dengan Gangguan Fungsi Ginjal Di Instalasi Rawat Inap Rsup Dr. Sardjito Yogyakarta Periode 2009-2013. Jurnal Ilmiah Farmasi, 12(1)

WHO. 2015. Cardiovaskuler diseases. Geneva : Whorld Healt Organisation. 